\title{
CORROSION OF GLASS USED FOR RADIOACTIVE WASTE DISPOSAL - STATE OF THE ART
}

\author{
${ }^{1}$ Ali AL DABBAS, ${ }^{2}$ Katalin KOPECSKÓ ${ }^{*}$ \\ ${ }^{1,2}$ Department of Engineering Geology and Geotechnics, Faculty of Civil Engineering \\ Budapest University of Technology and Economics \\ Müegyetem rakpart 3, Budapest 1111, Hungary \\ e-mail: ${ }^{1}$ ali.al.dabbas@epito.bme.hu, ${ }^{2}$ kopecsko.katalin@epito.bme.hu
}

Received 3 January 2018; accepted 18 September 2018

\begin{abstract}
Iron corrosion products of the steel canister in the nuclear waste container are highly silica sorptive materials and very much expected to delay formation of the protective layer (gel) on the nuclear glass interface. This study is focusing on the role of the iron carbonates (ankerite), which is probably one of iron corrosion products and already exists in the clay structure of the disposal depth. French SON68 inactive reference glass (alternative to the R7T7type) samples are planned to leach in different series of experimental models with dissimilar quantities of natural ankerite. All batch experiments will be cultivated in synthetic CallovoOxfordian groundwater; where different $\mathrm{pH}$ (4-9) values and temperatures $\left(35,50,90{ }^{\circ} \mathrm{C}\right)$ are considered. In this paper the state of the art of the radioactive waste glass corrosion in the circumstances of deep geological disposal were extensively studied.
\end{abstract}

Keywords: Durability and corrosion of glass, Nuclear waste immobilization and deposition, Radioactive waste glass container, Ankerite

\section{Introduction}

Last century, nuclear energy started taking part in energy production and research sectors. The long life highly radioactive waste generated from the nuclear reactors is one of the critical issues regarding this. Spent fuel generated from the nuclear reactors is considered as High Level radioactive Waste (HLW). It requires sophisticated treatment and management to be successfully isolated from the biosphere [1] because it contains radionuclides subscribed in fission reactions (plutonium, minor actinides and fission

${ }^{*}$ Corresponding Author 
products). Disposal of the HLW in deep geological formation in multi-layer containers is agreed by the most involved countries and highly recommended by the International Atomic Energy Agency (IAEA). After evaporation of the volatile radionuclides it is immobilized and vitrified by incorporating into borosilicate glass matrix (R7T7 type glass) [2], [3]. The glass matrix is formed to pellet shape and poured into stainless steel containers to facilitate its handling, storage and disposal operations. Finally it is embedded in a buffer i.e. concrete isolation in the clay-stones [4].

\subsection{High level waste}

Nuclear power or research reactors use nuclear fuel as fuel rods consist of uranium oxide or Mix of uranium plutonium OXide (MOX). MOX is taking a cylindrical shape and it is encapsulated in metallic tubes, which are terminated after 3-7 years and removed from the core. Then the removed spent fuel is stored under re-circulated water pools for 9-12 months to insure effective decrease of the extremely high thermal and radioactive energies. Nuclear spent fuel mainly consists of (96-97\%) uranium plutonium and $(3-4 \%)$ fission products. Spent fuel is reprocessed (uranium and plutonium are separated) to generate new nuclear fuel used in economic reactors and the remaining fission products $\left({ }^{129} \mathrm{I},{ }^{90} \mathrm{Sr},{ }^{99} \mathrm{Tc},{ }^{79} \mathrm{Se},{ }^{36} \mathrm{Cl}\right.$, and $\left.{ }^{135} \mathrm{Cs}\right)$ and other actinides are considered as HLW. In particular, some radioactive isotopes such as ${ }^{99} \mathrm{Tc},{ }^{79} \mathrm{Se}$, and ${ }^{129} \mathrm{I}$ are mobile in water, requiring special storage medium that reduces their ability to move into the groundwater [5], [6].

\subsection{Immobilization of the $H L W$}

Immobilization of the HLW is a kind of treatment and conditioning. This process reduces the waste volume by converting liquid actinides and other high-level radioactive waste into solid shape. It is expected to reduce the potential hazard of the highly radioactive waste, and this will help to make it easier for being stored and handled, as well as this process will potentially reduce the leak hazard of this kind of waste [7]. One of the most common and confirmed immobilization methods is the vitrification. It is confirmed as the basic technology for radioactive waste disposal worldwide. Vitrification is calcination of the HLW and then incorporation it into borosilicate glass to be as glass matrix material. Then it is poured into stainless steel canisters. Finally, non-recoverable fission products and actinides became locked in the glass matrix insoluble in water and stable for hundreds of thousands of years [8].

\subsection{Storage and disposal of HLW}

HLW cannot be fully retired or recycled; therefore, it requires a reliable and secure storage for hundreds of thousands of years. Disposal of HLW is a long-term storage in a deep geological disposal located between 450 and $500 \mathrm{~m}$ depth generally in an argillaceous Callovo-Oxfordian (COx) formation [9], [10] in a multi-layer container where tectonic stability is great and natural barrier are effective to contain that kind of waste. Very important issue must be assured that this waste should be disabling to get 
back in life resources of the future generations and prevent the transfer of radionuclides to the biosphere on time scales up to millions of years [4].

\section{Glass corrosion}

Formation of alteration layer on glass in the COx geological formation has been studied as well as experimentally evaluated and determined by several studies. The long-term storage was experimentally estimated by evaluating the effects of the physico-chemical parameters on the short-term alteration of glass such as $\mathrm{pH}$, temperature, glass composition and redox potential [9], [11].

\subsection{Glass dissolution}

In water saturated surroundings dissolution of glass is a result of various processes:

First: hydration of glass is taking place by water diffusion into the glass network followed by ion exchange between positive protons already exists in the COx groundwater and alkali metals in the glass formation, which leads to hydration of glass and formation of amorphous alteration layer (gel) on the glass surface due to mass loss of glass in the silica saturated environment.

Second: hydrolysis of the ionic-covalent bonds of the most soluble elements by attacking the glass network ( $\mathrm{Si}-\mathrm{O}-\mathrm{X} ; \mathrm{X}: \mathrm{Si}, \mathrm{Al}, \mathrm{Fe}, \mathrm{Zr}$ ) bonds by $\mathrm{COx}$ groundwater.

Third: condensation mechanism where the silica is reversely reacts and dissolves in the $\mathrm{COx}$ groundwater and condensate as a gel layer influenced by $\mathrm{pH}$ and temperature. The leaching solution should be saturated by $\mathrm{Si}$ as a condition necessary for the formation of the gel layer [9], [12], [13], [14].

\subsection{Function of the gel layer}

The gel layer is considered as a natural phenomenon happening to reduce the direct contact between the groundwater and the glass to protect the glass from dissolving in the groundwater and so prevent potential release of the radioactive substances back to the biosphere which is extremely harmful on the human life resources [15], [16], [17]. The Iron Corrosion Products (ICPs) in the solution will provide surfaces for Si sorption, which is responsible for binding silica and reducing $\mathrm{Si}$ content in the surrounding formation. This is expected to delay the creation of gel layer in the insufficient $\mathrm{Si}$ saturated solution, and so, this will motivate glass dissolution [18].

\subsection{Iron corrosion products}

Microbial Influenced Corrosion (MIC) is highly expected to happening on the carbon steel canister of the nuclear waste in the anaerobic conditions deep in the geological repository formation. Steel alteration in presence of bacterial activities should not be ignored. It is considered as a basic factor responsible to accelerating exponentially rising ICPs [10], [19]. Sulphate Reducing Bacteria (SRB) are considered 
as the main reason of MIC in the anaerobic conditions. They belong to special group of microorganisms that use the sulphates exist in the medium as a thermal electron acceptor for respiration and it generates hydrogen sulphide as a terminal product [20]. SRB are member of the taxonomically diverse microorganisms group which is classified as anaerobic active group [19]. SRB accelerate the steel corrosion rate and induce the stress and pitting corrosion of metals. Their main effect is that they breathe the sulphur and all of its compounds as sulphate, sulphite, etc. to produce a sulphide or hydrogen sulphide as a by-product of the breathing metabolism process as well as they produce $\mathrm{H}_{2}$ in the process formation of iron sulphide, FeS [21], [22]. SRB exist widely in deep geological repository and they influence iron corrosion by releasing free Fe ions in the solution surroundings the glass, which are expected to create different kinds of iron carbonate minerals [23].

\section{Silica sorption}

Experiments have been performed by the joint Japanese (Central Research Institute of Electric Power Industry, CRIEPI, Tokyo), Swiss (National Cooperative for the Storage of Radioactive Waste, NAGRA, Baden), Swedish (Swedish Nuclear Fuel and Waste Management Company, SKB, Stockholm) international project (JSS) on determination of the chemical durability of the French nuclear waste borosilicate glass (R7T7 type glass), which was completed in 1988. The experiments were performed with glass samples closely simulating the nominal R7T7 composition. Radioactive and nonradioactive specimens were investigated. The experiments determined the chemical durability of R7T7 and, at the same time to better understand the glass corrosion and the performance of the French glass under potential disposal conditions in the repository medium. Silica saturation achieved in 91 days at $90{ }^{\circ} \mathrm{C}$. Glass corrosion rate was measured 1000 times lower after Si saturation [24].

Nuclear waste is providing higher temperature and MIC mechanism is enhancing the lower $\mathrm{pH}$ by producing acidic by-products. All of that will provide appropriate medium conditions for $\mathrm{Si}$ sorption mechanism on the ICPs, which were experimented and showed enhancing and accelerating effect on the corrosion process of the borosilicate glass [25], [26].

\subsection{Power of ICPs to uptake silicon}

Bacterial activities on the different carbon steel applications in both anaerobic and aerobic mediums have shown ICPs whether iron carbonates (i.e. siderite, $\mathrm{FeCO}_{3}$ ) or iron oxides (i.e. magnetite, $\mathrm{Fe}_{3} \mathrm{O}_{4}$; goethite, $\alpha-\mathrm{FeOOH}$ ) in the bulk medium [11], [23], [27]. An experiment conducted on the SON68 type glass (inactive analogue of the French candidate - R7T7 - for HLW vitrification) [28], representative iron corrosion products have shown strong influence on the alteration of the SON68 glass. The primary analyses of the powder obtained from corrosion layer of archaeological iron artifacts (representative ICPs) under experimental conditions (i.e. $50^{\circ} \mathrm{C}$, COx groundwater medium and anoxic conditions) resulted in formation of ICPs precipitation consisting of 
siderite, magnetite and chukanovite $\left(\mathrm{Fe}_{2}\left(\mathrm{CO}_{3}\right)(\mathrm{OH})_{2}\right)$. The ICPs precipitates lowered the $\mathrm{Si}$ concentration in the solution and so it sustains the glass dissolution unstoppable.

When magnetite and goethite were added to the solution they showed deleterious effect on the chemical durability of the glass [13]. It was justified by Si sorption on the outer surface of the ICPs. They shown differentiation in power of Si sorption, for instance, goethite showed 4 times higher $\mathrm{Si}$ sorption capacity than magnetite and siderite under maximum $\mathrm{pH} 8.5$ medium. It was clear that the released $\mathrm{Si}$ from the glass to the solution was consumed by the ICPs, and that increased the glass corrosion like 5 times more [24]. So ICPs have accelerated the glass dissolution and negatively influenced on the glass durability. Additional reason for accelerating the glass alteration is the precipitation of the iron-silicates, which showed delay on silica saturation in the solution. Therefore, all reasons influence the silicate saturation reach in the solution will do indirect influence on the glass alteration; $\mathrm{Si}$ sorption by the precipitated $\mathrm{Fe}$ oxides/carbonates and the dissolved Fe(II) in the solution, which is expected to do so by interacting with $\mathrm{Si}$ in the solution or incorporated within the gel porosity [14]. However, zero glass dissolution-rate was obtained due to clogging of the external gel porosity at the gel/Si saturated solution after about one month of leaching under certain conditions [29]. This specifies that vitrification process of the HLW in Si saturated medium is very effective and practical solution for immobilization of the HLW in the long-term storage [30].

\subsection{Formation and role of ankerite}

Ankerite is present in the clayey matrix and its dissolution showed goethite $\mathrm{FeOOH}$ formation [31]. Siderite in the carbonatites in the past has approved to be ankerite, $\mathrm{Ca}(\mathrm{Fe}, \mathrm{Mg}, \mathrm{Mn})\left(\mathrm{CO}_{3}\right)_{2}$ [32]. Ankerite $\left(\mathrm{CaFe}\left(\mathrm{CO}_{3}\right)_{2}\right)$ has the same crystal structure as dolomite $\left(\mathrm{CaMg}\left(\mathrm{CO}_{3}\right)_{2}\right)$ [33] and considered as a member of the dolomite group of minerals and it shares siderite many of similarities [34]. Siderite, ankerite and dolomite have shown up significant identified precipitation in the sandstone, when Fe(II) source provider was exist there [33], [35].

MIC mechanisms on the steel canister release Fe(II), which most likely sufficient to precipitate ankerite. So, this study is predicting ankerite precipitation as one of the ICPs. Natural ankerite is already taking part in mineralogical composition of the CallovoOxfordian host-rock [36], [37] as well as it is one of the main chemical compositions of the carbonates in the Callovian-Oxfordian formations [38]. Fe(II) solubility and redox potential in the deep geological formation are important parameters and should be studied the possibility of future changes in the solubility products for ankerite. Therefore; more research work is needed to constrain the solubility of additional phases of equilibrium, e.g. ankerite, that could influence the Fe(II) concentrations. On the other hand a very slight bacterial perturbation can lead to major changes in $\mathrm{Fe}(\mathrm{II})$ concentration values [36], [38] and this induce a new hypothesis that SRB are influencing indirectly the durability of glass. 


\section{Experimental parameters influencing the alteration of HLW glass}

All experimental circumstances shall represent the real conditions and meet as much as it is possible the actual glass corrosion event, which is taking place in deep geological repository. All materials have been used are special in composition and have been prepared in a standard methods.

\subsection{Clay}

Scientific researchers are using drilled out clay from deep geological formation in selected countries where the HLW could be disposed, so, they can determine the alterations of the nuclear waste packages in the clay rich in minerals. These include France (Callovo-Oxfordian Clayrock at Bure), Belgium (Boom Clay at Mol), Hungary (Boda Claystone at Mecsek), Switzerland (Opalinus Clay at Mont Terri and Benken, and Palfris Formation at Wellenberg), United Kingdom (Oxford Clay), and Canada (Queenston Formation) [31], [36], [39]. French (Callovo-Oxfordian Clayrock at Bure) has been selected for the present work (Table I).

\section{Table I}

Mineralogical composition of the Callovo-Oxfordian host-rock Range of weight composition (wt.\%) [14], [36]

\begin{tabular}{|l|l|}
\hline \multicolumn{1}{|c|}{ Mineral } & \multicolumn{1}{c|}{ Composition,wt.\% } \\
\hline Mica+illite & $11-17$ \\
Interstratified illite-smectite & $27-31$ (30-60 wt.\% smectite) \\
Chlorite & 2.0 \\
Kaolinite & $1.5-2.6$ \\
Plagioclase feldspars & 1.0 \\
Potassic feldspars & 1.9 \\
Quartz & $22-25$ \\
Calcite & $20-21$ \\
Dolomite/ Ankerite & 3.0 \\
Anatase/rutile & 0.3 \\
Pyrite & $0.7-0.8$ \\
Goethite/siderite & $1.6-1.9$ \\
\hline
\end{tabular}

\subsection{Glass}

SON68 type glass is the inactive analogue of the French high-level waste glass (R7T7-type). The composition of the SON68 glass is shown in Table II. There are many researches where the durability of this inactive glass was studied instead of studying the radioactive material [2], [3], [9], [14], 18], [28], [29], [30].

Future experiments is planned to be conducted over small polished glass chips/coupons, involving accelerated ageing of glass due to model environment. 


\subsection{COx Groundwater}

To realize the groundwater in the medium of the Callovo-Oxfordian formation; a synthetic water (COx groundwater) is going to be prepared especially to this experiment. It is originally Ultra-Pure Water (UPW) under addition of some nutrients and organic carbon. Table III illustrates the components, which will be added experimentally to the UPW.

Table II

Chemical composition in weight of the inactive SON68 nuclear glass [9]

\begin{tabular}{|c|c|c|c|}
\hline Oxide & Composition, wt.\% & Oxide & Composition,wt.\% \\
\hline $\mathrm{SiO}_{2}$ & 45.85 & $\mathrm{MoO}_{3}$ & 1.78 \\
$\mathrm{~B}_{2} \mathrm{O}_{3}$ & 14.14 & $\mathrm{Cs}_{2} \mathrm{O}$ & 1.12 \\
$\mathrm{Na}_{2} \mathrm{O}$ & 10.22 & $\mathrm{BaO}$ & 0.62 \\
$\mathrm{Al}_{2} \mathrm{O}_{3}$ & 5.00 & $\mathrm{Y}_{2} \mathrm{O}_{3}$ & 0.20 \\
$\mathrm{CaO}$ & 4.07 & $\mathrm{La}_{2} \mathrm{O}_{3}$ & 0.93 \\
$\mathrm{Li} \mathrm{O}_{2} \mathrm{O}$ & 1.99 & $\mathrm{Nd}_{2} \mathrm{O}_{3}$ & 2.04 \\
$\mathrm{Fe}_{2} \mathrm{O}_{3}$ & 3.03 & $\mathrm{Pr}_{2} \mathrm{O}_{3}$ & 0.46 \\
$\mathrm{NiO}$ & 0.43 & $\mathrm{Ag}_{2} \mathrm{O}$ & 0.03 \\
$\mathrm{Cr}_{2} \mathrm{O}_{3}$ & 0.53 & $\mathrm{CdO}$ & 0.03 \\
$\mathrm{ZnO}$ & 2.53 & $\mathrm{SnO}_{2}$ & 0.02 \\
$\mathrm{P}_{2} \mathrm{O}_{5}$ & 0.29 & $\mathrm{TeO}_{2}$ & 0.23 \\
$\mathrm{SrO}$ & 0.35 & $\mathrm{Ce}_{2} \mathrm{O}_{3}$ & 0.97 \\
$\mathrm{ZrO}_{2}$ & 2.75 & $\mathrm{Others}^{2}$ & 0.39 \\
\hline
\end{tabular}

Table III

Composition of the synthetic argillite water (COx water) [10]

\begin{tabular}{|c|c|c|c|}
\hline Compound & $\begin{array}{c}\text { Concentration, } \\
\text { mole/ } 1\end{array}$ & Compound & $\begin{array}{c}\text { Concentration, } \\
\text { mole/ } 1\end{array}$ \\
\hline $\mathrm{Fe}$ & $3.40 \mathrm{E}-05$ & $\mathrm{Na}$ & $4.56 \mathrm{E}-02$ \\
$\mathrm{Sr}$ & $2.00 \mathrm{E}-04$ & $\mathrm{TIC}$ & $3.34 \mathrm{E}-03$ \\
$\mathrm{~K}$ & $1.03 \mathrm{E}-03$ & $\mathrm{Si}$ & $1.80 \mathrm{E}-04$ \\
$\mathrm{Mg}$ & $6.67 \mathrm{E}-03$ & $\mathrm{Cl}$ & $4.10 \mathrm{E}-02$ \\
$\mathrm{Ca}$ & $7.36 \mathrm{E}-03$ & $\mathrm{NH}_{4}$ & $2.90 \mathrm{E}-04$ \\
$\mathrm{Al}$ & $4.70 \mathrm{E}-09$ & $\mathrm{Mn}$ & $4.70 \mathrm{E}-06$ \\
$\mathrm{SO}_{4}$ & $1.56 \mathrm{E}-02$ & Lactate & $8.00 \mathrm{E}-06$ \\
\hline
\end{tabular}

\section{Conclusions}

High level radioactive wastes are immobilized and vitrified by incorporating into borosilicate glass matrix (R7T7 type glass). This glass matrix is poured then into stainless steel containers. Finally it is embedded in a buffer i.e. concrete isolation in the clay-stones of deep geological disposal. In this paper the state of the art of the corrosion of radioactive waste glass in the circumstances of deep geological disposal were extensively studied. Microbial influenced corrosion is highly expected to happening on 
the carbon steel canister of the nuclear waste in the anaerobic conditions deep in the geological repository formation. Steel alteration in presence of bacterial activities is proved as a basic factor responsible to accelerate the formation the iron corrosion products. Ankerite should be considered as one of the important iron carbonates, which is suggested to take part in the iron corrosion products in addition to its ubiquitous in soils. Therefore; it is highly expected to be additional factor influencing the glass alteration in the disposal repository formation in addition to the factors already studied by the literature. Ankerite could have multifunctional (direct and indirect) effects on the alteration of glass, which hypothesis should be experimentally proved.

\section{Acknowledgement}

Stipendium Hungaricum Scholarship Programme is highly acknowledged for supporting the $\mathrm{PhD}$ study and research work. Authors are acknowledged having the opportunity to present the paper at the $13^{\text {th }}$ Miklós Iványi International PhD \& DLA Symposium (Pécs, Hungary).

\section{Open Access statement}

This is an open-access article distributed under the terms of the Creative Commons Attribution 4.0 International License (https://creativecommons.org/licenses/by/4.0/), which permits unrestricted use, distribution, and reproduction in any medium, provided the original author and source are credited, a link to the CC License is provided, and changes - if any - are indicated. (SID_1)

\section{References}

[1] Musić S., Ristić M., Gotić M., Forić J. Corrosion of simulated nuclear waste glass, Journal of Radioanalytical and Nuclear Chemistry, Vol. 122. No. 1, 1988, pp. 91-102

[2] Minet Y., Bonin B., Gin S., Frugier P. Analytic implementation of the GRAAL model: Application to a R7T7-type glass package in a geological disposal environment, Journal of Nuclear Materials, Vol. 404, No. 3, 2010, pp. 178-202.

[3] Grambow B. Nuclear waste glasses - How durable? Elements, Vol. 2, No. 6, 2006, pp. 357364.

[4] Evaluation of the feasibility of a geological repository in an argillaceous formation, Report Series, Andra, France, 2005.

[5] Thompson L. Vitrification of nuclear waste, Coursework for Physics 240, Stanford University, Fall 2010, 2010.

[6] Storage and disposal of spent fuel and high level radioactive waste, International Atomic Energy Agency, 2006, https://www.iaea.org/About/Policy/GC/GC50/../English/gc50inf-3att5_en.pdf, (last visited 25 December 2017).

[7] Eaton G. F., Smith D. K. Aged nuclear explosive melt glass: Radiography and scanning electron microscope analyses documenting radionuclide distribution and glass alteration, Journal of Radioanalytical and Nuclear Chemistry, Vol. 248. No. 3, 2000, pp. 543-547.

[8] Treatment and conditioning of nuclear waste, Word Nuclear Association, 2017. 
[9] Bouakkaz R., Abdelouas A., El Mendili Y., Grambow B., Gin S. SON68 glass alteration under Si-rich solutions at low temperature $\left(35-90^{\circ} \mathrm{C}\right)$ : kinetics, secondary phases and isotopic exchange studies, RSC Adv, Vol. 6, 2016, pp. 72616-72633.

[10] El Hajj H., Abdelouas A., Grambow B., Martin C., Dion M. Microbial corrosion of P235GH steel under geological conditions, Physics and Chemistry of the Earth, Parts $A / B / C$, Vol. 35, No. 6-8, 2010, pp. 248-253.

[11] Féron D., Crusset D., Gras J. M. Corrosion issues in nuclear waste disposal, Journal of Nuclear Materials, Vol. 379, No. 1-3, 2008, pp. 16-23.

[12] Gin S. Open scientific questions about nuclear glass corrosion, Procedia Materials Science, Vol. 7, 2014, pp. 163-171.

[13] Philippini V., Naveau A., Catalette H., Leclercq S. Sorption of silicon on magnetite and other corrosion products of iron, Journal of Nuclear Materials, Vol. 348, No. 1-2, 2006, pp. 60-69.

[14] Burger E., Rebiscoul D., Bruguier F., Jublot M., Lartigue J. E., Gin S. Impact of iron on nuclear glass alteration in geological repository conditions: A multiscale approach, Applied Geochemistry, Vol. 31, 2013, pp. 159-170.

[15] Rebiscoul D., Frugier P., Gin S., Ayral A. Protective properties and dissolution ability of the gel formed during nuclear glass alteration, Journal of Nuclear Materials, Vol. 342, No. 1-3, 2005, pp. 26-34.

[16] Vernaz E., Gin S., Jegou C., Ribet I. Present understanding of R7T7 glass alteration kinetics and their impact on long-term behavior modeling, Journal Nuclear Materials, Vol. 298, No. 1-2, 2001, pp. 27-36.

[17] Gin S., Ribet I., Couillard M. Role and properties of the gel formed during nuclear glass alteration: Importance of gel formation condition, Journal Nuclear Materials, Vol. 298, No. 1-2, 2001, pp. 1-10.

[18] Curti E. Glass dissolution parameters, Technical Report, No. PSI-03-18, Paul Scherrer Institut, CH-5232 Villigen PSI (Switzerland), INIS Vol. 36, No. 3, 2003. p. 62.

[19] Kuang F., Wang J., Yan L., Zhang D. Effects of sulfate-reducing bacteria on the corrosion behavior of carbon steel, Electrochimica Acta, Vol. 52, No. 20, 2007, pp. 6084-6088.

[20] Sagues A. A., Poor N. D., Gaseres L., Akhoondam M. Development of rational method for predicting corrosion rate of metals in solids and water, Final Report to Florida Department of Transportation, University of South Florida, 2009.

[21] Beech I. B. Sulfate-reducing bacteria in biofilms on metallic materials and corrosion, Microbiology Today, Vol. 30. No. 3, 2003, pp. 115-117.

[22] Harbuláková V., Eštoková A., Luptáková A., Števulová N., Janák G. Concrete specimens biodeterioration by bacteria of Acidithiobacillus thiooxidans and desulfovibrio genera, Pollack Periodica, Vol. 4, No. 1, 2009, pp. 83-92.

[23] Little B. J., Lee J. S., Ray R. I. Diagnosing microbiologically influenced corrosion: A stateof-the-art review, Corrosion, Vol. 62, No. 11, 2006, pp. 1006-1017.

[24] Werme L., Bjorner I. K., Bart G., Zwicky H. U., Grambow B., Lutze W., Ewing R. C., Magrabi C. Chemical corrosion of highly radioactive borosilicate nuclear waste glass under simulated repository conditions, J. Material Research, Vol. 5, No. 5,1990, pp. 1130-1146.

[25] Bart G., Zwicky H. U., Aerne E. T., Graber T. H., Z’Berg D., Tokiwai M. Borosilicate glass corrosion in the presence of steel corrosion products, Materials Research Society fall meeting, Boston, MA, USA, 1-5 December 1986, Vol. 18, No. 22,1986, pp. 459-470.

[26] Mitsui S., Aoki R. Effect of siliceous additive on aqueous alteration of waste glass with engineered barrier materials, Journal of Nuclear Materials, Vol. 298, No. 1-2, 2001, pp. 184-191.

[27] Jordan N., Marmier N., Lomenech C., Giffaut E., Ehrhardt J. J. Sorption of silicates on goethite, hematite, and magnetite: Experiments and modeling, Journal of Colloid and Interface Science, Vol. 312, No. 2, 2007, pp. 224-229. 
[28] Dillmann P., Gin S., Neff D., Gentaz L., Rebiscoul D. Effect of natural and synthetic iron corrosion products on silicate glass alteration processes, Geochimica et Cosmochimica Acta, Vol. 172, 2016, pp. 287-305.

[29] Jollivet P., Angeli F., Cailleteau C., Devreux F., Frugier P., Gin S. Investigation of gel porosity clogging during glass leaching, Journal of Non-Crystalline Solids, Vol. 354, No. 45-46, 2008, pp. 4952-4958.

[30] Icenhower J. P., Steefel C. I. Experimentally determined dissolution kinetics of SON68 glass at $90{ }^{\circ} \mathrm{C}$ over a silica saturation interval: Evidence against a linear rate law, Journal of Nuclear Materials, Vol. 439, No. 1-3, 2013, pp. 137-147.

[31] Breitner D., Osán J., Fábián M., Zagyvai P., Szabó C., Dähn R., Fernandes M. M., Sajó I. E., Máthé Z., Török S. Characteristics of uranium uptake of Boda Claystone formation as the candidate host rock of high level radioactive waste repository in Hungary, Environmental Earth Sciences, Vol. 73, No. 1, 2015, pp. 209-219.

[32] Buckley H. A., Woolley A. R. Carbonates of the magnesite-siderite series from four carbonatite complexes, Mineralogical Magazine, Vol. 54, No. 376, 1990, pp. 413-418.

[33] Chai L., Navrotsky A. Synthesis, characterization, and energetics of solid solution along thedolomite-ankerite join, and implications for the stability of ordered $\mathrm{CaFe}\left(\mathrm{CO}_{3}\right)_{2}$, American Mineralogist, Vol. 81, No. 9-10, 1996, pp. 1141-1147.

[34] Amethyst Galleries' Mineral Gallery, Ankerite, http://www.galleries.com/Ankerite, (last visited on 24 December 2017).

[35] Xu T., Apps J. A., Pruess K. Mineral sequestration of carbon dioxide in a sandstone - shale system, Chemical Geology, Vol. 217, No. 3-4, 2005, pp. 295-318.

[36] Gaucher E. C., Tournassat C., Pearson F. J., Blanc P., Crouzet C., Lerouge C., Altmann S. A robust model for pore-water chemistry of clayrock, Geochimica et Cosmochimica Acta, Vol. 73, No. 21, 2009, pp. 6470-6487.

[37] Lerouge C., Vinsot A., Grangeon S., Wille G., Flehoc C., Gailhanou H., Gaucher E. C., Madé B., Altmann S., Tournassat C. Controls of $\mathrm{Ca} / \mathrm{Mg} / \mathrm{Fe}$ activity ratios in pore water chemistry models of the Callovian-Oxfordian clay formation, Procedia Earth and Planetary Science, Vol. 7, 2013, pp. 475-478.

[38] Tournassat C., Lerougea C., Blanc P., Brendlé J., Greneche J. M., Touzelet S., Gaucher E. C. Cation exchanged $\mathrm{Fe}(\mathrm{II})$ and $\mathrm{Sr}$ compared to other divalent cations $(\mathrm{Ca}, \mathrm{Mg})$ in the bure Callovian-Oxfordian formation: Implications for pore-water composition modeling, Applied Geochemistry, Vol. 23, No. 4, 2008, pp. 641-654.

[39] Buocz I., Rozgonyi-Boissinot N., Török Á., Görög P. Direct shear strength test on rocks along discontinuities, under laboratory conditions. Pollack Periodica, Vol. 9, No. 3, 2014, pp. $139-150$. 